\title{
When Good Management Isn’t Enough: The Story Of A Czech Business In The Twentieth Century
}

Vicki R. TenHaken, (Email: tenhaken@hope.edu), Hope College

\begin{abstract}
We teach management as a rational process: if you conscientiously apply the concepts learned, you will succeed. However, for this equation to work certain underlying factors must be in place. No matter how well prepared managers may be, events unfold around them that profoundly affect their organizations. We may take the basic infrastructure of democratic capitalism for granted when we teach management education, but it doesn't hurt to remind our students occasionally that these 'givens' aren't always there. By teaching our students to appreciate how remarkable is the achievement of democratic capitalism, will we be more likely to protect it and perhaps even improve upon it.
\end{abstract}

\section{Introduction}

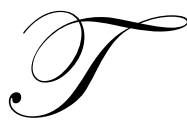

he premise behind our work in management education is that we can teach people how to be good managers. Underlying this premise is another: that the decisions and actions of a manager make a difference in the performance of the organization. Rita Gunther McGrath, Associate Professor of Management at Columbia University and co-chair of the 2003 Strategic Management Society annual international conference, challenged attendees at the conference in Baltimore last November to "examine the 'givens' in our field." An example of challenging accepted wisdom through research, she said, was recent work done by Carl Koch showing that a company's stock price isn't necessarily a good reflection of corporate performance. ${ }^{1}$

In this paper, I will attempt to explore the accepted wisdom that managers decisions and actions affect a firm's success. There are perhaps many ways of going about this. The approach I have chosen was suggested by Harvard professor Clay Christensen, author of several publications on innovation, ${ }^{2}$ on how to structure good research: look for the anomalies. Rather than discounting the anomalies as aberrations, he says we should study them for how they can help us refine our theories. The anomaly (to the theory that management decisions and actions determine the success of the firm) I chose to study is that of a Czech business over the course of the $20^{\text {th }}$ century. As you will see, despite heroic efforts on the part of the managers, the business failed. Could the managers have made different decisions? Certainly, they could have. However, I believe the forces at play in this case were such that no decisions or actions on the part of the company's managers could have saved the firm. Not a change in strategy, not better execution, not better environmental scanning, not better communication, not better controls..... nothing the managers could have done would have made a difference. ${ }^{3}$

\section{The J. Metzker Krawattenfabrik Story}

Alois Metzker was a peddler who in 1869 was granted permission to live in Votice, Bohemia. ${ }^{4}$ His family eventually moved to Prague (Praha) and his son, Joseph, started a necktie factory called the J. Metzker Krawattenfabrik. This business operated from a prestigious address at \#5 Mustek (Na Mustku 5) - even today the "high rent" retail area of Prague. Pictures of the family during the early part of the $20^{\text {th }}$ century show well-dressed, elegant people. There is also a picture of one of Joseph's sons in an army uniform. 
Common practice of the day would have been to have the cutting and sewing operations of the business take place on an upper floor of the building with the store itself on the street level. The family likely lived on the uppermost floor of their building, though it is possible they lived in the Jewish quarter. Joseph died in 1939 and his wife Marie continued to run the J. Metzker company. Trouble for the business (and for the Metzkers) began in 1942 when the Nazis confiscated the business and "sold" it to two Germans, who renamed the business Marquis. ${ }^{5}$ Marie and her adult children were sent to Terezin, the Nazi "work" camp.

Amazingly, 73-year-old Marie Metzkerova survived her three years in Terezin, though at least one of her children died in Auschwitz. After being freed from Terezin, Marie moved back to Prague and began the process of reclaiming her business. Official records show she was successful - to a point. She was able to regain control of the business' name and any original inventory. However, during the war years, Marquis had shifted production to undergarments and other more practical things and the governing board determined that Marquis could continue operating its current business - which was all that was left of the J. Metzker Krawattenfabrik. So in actuality, all Marie received was a license to produce and sell ties under the name J. Metzker \& Co. However, other records indicate she was given permission to operate this business at the original address of Mustek \#5, so one can assume she was also given back the building which housed the original family business. ${ }^{6}$

Marie's success was short lived. The government required the J. Metzker company to join the "guild" of textile producers. Soon the company was forced to become part of the United Linen Producers, a "people-owned" state collective, and was told it could no longer produce neckties, but rather must make garments more useful to the population. At the same time, all management decisions were moved to the government officials in charge of the cooperative, a government appointed overseer was put in place, and any association the Metzkers had with the business was terminated. Not only was the business taken away, but the legal documents instructed that, if Marie or any family member tried to interfere with the operation of the business, they would go to jail and be fined 10 million crowns! $!^{7}$ Marie Metzkerova died in March of 1947 and her surviving children left the country. After first losing their business to the Nazis, but surviving the war and reclaiming it, they now lost the business a second time - to the communists.

\section{Summary}

So what, if anything, can we learn from this story? It is certainly not an uncommon $20^{\text {th }}$ century story in many Eastern European countries. Was there some action the managers could have taken to save the company? One question that comes to mind is whether the managers did an adequate job of environmental scanning. Even though there were external forces beyond the control of the managers, isn't it management's task to see the signs of such forces ahead of time and put in place contingency plans if such forces cannot be influenced or avoided? Don't we teach our students that one of the first tasks of planning is to conduct a situation analysis, scanning the external environment to identify possible threats? And once such threats are identified, to move to prevent or diffuse them? If prevention isn't possible, then a manager should prepare in advance with alternative, or contingency plans. But what could the managers of the J. Metzker Krawattenfabrik have done? There are indications they tried to take some preventative actions: At least one son enlisted in the army, presumably to prove the family's loyalty to their country. If their "early warning system" had told them they would be sent to Terezin and they had been able to flee the country, how would that have helped save the business? And even if they had managed to continue to operate their company during the war years, it still would have faced extinction under the communist regime. ${ }^{8}$

Rather, I think the lesson we learn from this anomaly is that our theory that a manager's actions and decisions affect a firm's performance only works in a political environment that allows some semblance of a free market economy. That our theory only works in an environment where the government can't replace management because of their race or religion. That our theory only works in an environment where the government can't take over your business or dictate what you will produce. These are things we take for granted when we teach management education. But perhaps it doesn't hurt to remind our students occasionally that these 'givens' weren't always there. Only by appreciating the necessity of these underlying factors will we be sure to protect them and keep them. 
In the senior management seminar at Hope College, I devote nearly one-third of the curriculum to studying the morality of capitalism. By discussing readings of people as diverse as Adam Smith, Karl Marx, E.F. Schumacher, Michael Novak, Peter Drucker and Max DePree ${ }^{9}$, our students come to the realization that democratic capitalism is truly a remarkable achievement. James Q. Wilson in his article on Capitalism and Morality ${ }^{10}$ states that it has become clear during the last half century that democratic regimes only flourish in capitalist societies. "Not every nation with something approximating capitalism is democratic, but every nation that is democratic is, to some significant degree, capitalist." "11 If capitalism is an economic success and the necessary (but not sufficient) precondition for democracy, then (Wilson argues), it only remains vulnerable on cultural and moral grounds. Through an exploration of the critiques and defenses of capitalism, most students realize that the business environment they will be entering is not one they should take for granted. They grapple with some of the problems that result from such a system and also discuss some propositions that might improve it, such as "inclusive capitalism"12 and "natural capitalism." James Surowiecki, a business columnist for the New Yorker, writes that "The relationship between capitalism and humanitarianism is essentially invisible now: The ideas it depends on have become part of the background of everyday life. The same is true of the commonplace workings of a healthy capitalist system...... But in fact they're remarkable achievements." ${ }^{14}$ Surowiecki concludes his article by saying this is a lesson we periodically need to be reminded of or we risk having to learn it all over again. I don't want our future leaders to realize too late the beauty of a system they take for granted. We hope to instill in our students an understanding of the need to continue to protect, develop and even improve on this "remarkable achievement."

\footnotetext{
1 "The Impact of Financial Markets on Firm Behavior and the Role of Executive Compensation: Empirical Evidence," Carl Joachim Kock, Instituto De Empresa, conference proceedings, Strategic Management Society Annual International Conference, November 2003, pp 14-15.

${ }^{2}$ Clayton M. Christensen, Robert and Jane Cizik Professor of Business Administration, Harvard Business School. Presentation notes from keynote speech at Strategic Management Society Annual International Conference, November 2003. Books include "The Innovator's Dilemma," "Innovation and the General Manager," and "The Innovator's Solution."

${ }^{3}$ One could argue that closing the business in Prague, moving to another country and starting over was an option. However, I would counter that such an action still represents the failure of the original business.

${ }^{4}$ Letter dated July 25, 2002 from PhDr. Eva Prochazkova, Director of Statni Okresni Archiv Benesov

${ }^{5}$ Officially the business was sold for 1.4 million crowns, but the money was deposited into a bank account from which the money could be spent without Marie's knowledge.

${ }^{6}$ Extracts from the 1946 and 1947 Prague trade register, letter dated March 9, 2001 from PhDr.Vaclav Ledvinka, CSc., Director of Prague Municipal Archives

${ }^{7}$ Ibid

${ }^{8}$ Though there is certainly room for disagreement, I would argue that since the owners, managers and products being produced all changed and the name and company no longer existed, that the business was extinct even though some former workers may have continued to be employed by the cooperative.

${ }^{9}$ Partial reading list for MGMT400: Wealth of Nations by Adam Smith; Marx's Concept of Man by Erich Fromm; Small is Beautiful by E.F. Schumacher; Capitalism and Morality by James Q. Wilson; Virtuous Self-Interest by Michael Novak; A Virtuous Cycle by James Surowieki; Whither Capitalism? and Who Owns This Place? by Max DePree; From Capitalism to Knowledge Society by Peter Drucker; The Capitalist Century by Geoffrey Colvin ${ }^{10}$ James Q. Wilson, "Capitalism and Morality,” The Public Interest, Fall 1970, 42-55.

${ }^{11} \mathrm{Ibid}, 43$.

${ }^{12}$ Max DePree, Leadership Is An Art (East Lansing, Michigan: Michigan State University Press, 1987), 59-68.

${ }^{13}$ Amory B. Lovins, L. Hunter Lovins and Paul Hawken, “A Road Map for Natural Capitalism," Harvard Business Review, May-June 1999, 145-158.

${ }^{14}$ James Surowiecki, “A Virtuous Cycle,” Forbes, December 12, 2003, 255-256.
} 